FOREWORD

\begin{tabular}{l|l} 
Jacob Olupona & UNDERSTANDING POVERTY AND ITS
\end{tabular}

ALLEVIATION IN AFRICA AND THE AFRICAN

DIASPORA AN INTERDISCIPLINARY APPROACH

he essays in this volume critically examine the relationship between reli-
gion and poverty in African and African diasporic societies, problematizing the intersection of religion and poverty in the lives of the African peoples and their descendants in the Caribbean and North America. Emerging from a series of seminars and lectures held in several regions of Africa and the African diaspora over the past several years, the volume reflects the increasing convergence of theory, practice, and policy as it relates to the problem of poverty, its causes, and its alleviation. Though no central thesis guides the volume, it does suggest that, just as religious institutions and religious practices can contribute to and exacerbate poverty, religion can also play a potentially important role in poverty alleviation. Underpinning the evolving nexus between theory and practice is the difficult lesson that the academic pursuit of religious traditions must be seen in relation to the social and political situations under which faith communities live, flourish, and, at times, perish.

The volume sets out to provide an in-depth understanding of the problem of poverty in the experience of African people on both sides of the Atlantic, not only to examine the causes of poverty but also to provide answers for its alleviation in a way that will be beneficial to faith communities and the men and women currently struggling under the burden of poverty. In this volume, poverty as a concept and an analytical category is provided a broad, multidisciplinary focus in which phenomenological, theological, and sociological meanings and ethnographic investigation combine to provide an overview of 
the phenomenon. Though most of the scholars are theologians by training, the project is given a broader context than a purely doctrinal and scriptural investigation might have; it moves beyond the traditional notion of spiritual poverty set out in the Beatitudes: "Blessed are the poor in spirit: for theirs is the Kingdom of heaven" (Matt. 5:3) ${ }^{1}$ Rather, the essays in this volume tackle the existential and substantial meaning of poverty understood as the lack of daily necessities such as water, food, and medicine and as a reflection of the hideous social crises of our time such as disease, crime, violence, war, and prostitution. Locating poverty within the broad nexus of the social, cultural, and religious nexus of the postcolonial era in Africa, the contributors provide a necessary sense of urgency and realism, arguing convincingly that poverty disproportionately affects peoples of color who are the poorest of the poor in the global community.

\section{The Problem of Poverty}

The phenomenon of poverty is often best grasped in relation to other highly pertinent issues such as violence, bribery, and corruption, as well as prosperity and riches. Paul Bouvier calls our attention to the social reality of our time that "today the poor are no longer individuals, but entire nations that become increasingly poor, while other nations become increasingly rich." He sums up the most serious poverty predicament of our global world in these words: "today's proletariat consists of entire nations of victims of economic difficulties and the mechanisms of trade, carrying the burden of foreign debts and unable to overcome their lack of technological development." ${ }^{3}$ No statement better sums up the conditions and contexts under which millions of people of African descent live today. Several of the case studies set out in this volume show that abject poverty in many regions of the world is intimately connected to environmental mismanagement and the exclusion of the very people whose lands and resources have made other nations rich from a share of the wealth. A classic case of widespread suffering brought on by environmental mismanagement is the situation of the Ogoni people of Nigeria's Niger Delta region. In order to maintain its high levels of oil exploration, the state forcibly acquired Ogoni lands, disabling an entire region of the local resources and livelihood. The Ogoni were denied access to and control over both material resources and the social resources, processes, and institutions that defined and reinforced their place. An integrative approach to alleviating poverty is, then, best suited to the project of understanding poverty, as it reveals the connection and causal relationship between poverty and environmental crises in many African and diasporic societies. 
What, then is the nature of the poverty crisis? The comprehensive concept of poverty developed in this volume offers fresh insight and understanding into the problem of poverty in Africa and its diaspora. John Iliffe, who has written a substantial work on the African poor, classifies African poverty into two groups. One group comprises those who clearly "struggle continuously to preserve themselves and their dependents from physical want." Iliffe thinks that most Africans at some time fall into this level of poverty. The second group, fewer in number, is composed of the poorest of the poor and destitute, whose poverty has reached epidemic proportion. Facing starvation, they are beset by disease and malnutrition. ${ }^{4}$ Paradoxically, it seems to us that disproportionately high levels of poverty occur in countries with great visible wealth and resources, such as Nigeria, South Africa, and the Democratic Republic of Congo. Such profound poverty in the midst of plenty engenders anger and frustration on the part of civil society, who watch helplessly as their nation's wealth is looted by a small number of so-called filthy rich individuals and powerful international conglomerates. Echoing several of the theologians who contributed to the present volume, Father E. Mveng, a Cameroonian Catholic theologian, provides an encompassing and insightful description of poverty, or what he calls "anthropological poverty," which goes beyond "economic or financial deprivation": a deeper condition of poverty, a psychology in which one's own humanity is impoverished and one's very humanity is denied. ${ }^{5} \mathrm{~A}$ popular African proverb says that while "the poor person labors in the heat of the sun, the rich person enjoys the fruits of the labor under the shade" (osise wa l'oorun, eni maje wa ni $i b o j i$, as the Yoruba version goes). Found in various versions in other African societies, the proverb is a metaphor for the severity of the gap between the poor who work tirelessly to survive and the rich, the principal beneficiaries of the labor of the poor, who enjoy the enormous wealth generated from the fruits of the poor person's labor. The proverb further reflects the African and African diasporic condition and experience of poverty, the poor people's own understanding of their situation and lot in life under various historical and social situations, be they economic and social poverty and subhuman living conditions generated by the transatlantic and trans-Saharan slave trades, colonialism, postcolonial democracy, or military rule by African themselves.

As several chapters in this volume demonstrate, studying poverty in Africa and its diasporic communities requires that we begin with the poor's own description and understanding of their conditions and state of being. Whether these sources of knowledge are found in myths, rituals, metaphors, poetry, prose, or biographical narratives from the mouth of the common folks or from those Elizabeth Isichei calls "the village intellectuals," 
the narratives often describe the relationship between unequal individuals and peoples.

\section{Historical Causes of Poverty}

In analyzing the historical causes of poverty, we must look critically at the historical process and evolution of the continent from precolonial times through the colonial and postcolonial periods and examine the political economy of African states and the local and global forces that play central roles in the unfolding of the contemporary social life and situation of the people. No amount of synchronic understanding or ethnographic analysis on the present state of poverty on both sides of the African Atlantic society will do justice to the topic of our deliberation if we fail to acknowledge, even tangentially, the historical trajectory of poverty in Africa and African diaspora communities. While the centuries-long transatlantic slave trade laid the foundation for the current state of poverty in Africa and the African diaspora, the colonial legacy and the postcolonial condition of African people provide the background for the endemic nature of this crisis in Africa today. The slave trade led to the destruction of family, family values, communal and peaceful coexistence, and intergroup relations. As the demand for slaves increased exponentially in response to the insatiable demand in the Americas, warfare increased and the continent was deprived of its able-bodied men and women. The social disruption and depopulation that warfare and human trafficking wreaked on Africa over several hundred years gravely affected the human, social, and cultural development of the region. One can argue that Africa and the African diaspora people have not recovered from this human tragedy, a telling point that makes the request for reparations even more keenly felt.

There is no doubt that in the precolonial period-at least dating back to the early nineteenth century, when Africa had established empires, kingdoms, and states - there was both poverty and affluence. The poverty of that time, however, took a different form. As J. D. Y. Peel reminds us in the case of the Yoruba people, poverty as a social condition was intolerable and rejected as a way of life. ${ }^{7}$ A Yoruba proverb portrays the stigma associated with poverty: "It is better to die young with dignity than to become old in abject poverty" (Ki a ku lo'mode yeni, ju-ki a d'agba ka t'osi). Old age typically signals respectability, comfort, and dignity; what the Yoruba saying underlines is that an old age that brings misery and poverty is disgraceful. The proverb also illuminates a cardinal element of Yoruba religious thought and practice: the Yoruba profess a this-worldly worldview, and the indigenous 
Yoruba's religious quest to the orisa (gods) is that they provide to the supplicants the blessings of wealth, children, and long life (Ire owo, ire omo, ire emi gigun). The proverb's apparent rejection of the third of these blessings indicates the very high distaste the Yoruba have for abject poverty.

A more recent response to the crisis of communal and group poverty in African villages today is the growing link between ethno-religious identity and development. In Nigeria, Ghana, and other parts of Africa, for instance, village and town associations grow and meet in economic unity and social development. This often involves the reinvention of traditional value systems (of sacred kingship, totemic concepts, old lineage gods, and ancestors reinvented and reimagined in modern secular idioms). Although these groups are not necessarily linked to the worship of traditional gods, their members having largely converted to Islam and Christianity, they have established a platform for advancing economic unity and social development by appealing to the community as the sacred source of life. By invoking tribal myth and historic symbols and by galvanizing members of their communities at home and abroad to contribute to village, town, and community economic growth, they are responding to a crisis using their own metaphysical and epistemological worldview. Social, economic, and symbolic capital is rallied and tailored toward fighting communal poverty. These limited successes are unfortunately not matched by African governments, many of which have centralized control over natural resources. In general, traditional Africa was fairly well governed by traditional mores, customs, and laws that regulated the economy of the people and the nation-states in precolonial indigenous societies. There seems to have been greater accountability and greater commitment to the social welfare of the common people as well as significant checks and balances. Further, African beliefs and indigenous systems had real and symbolic meaning, and Africans were protective of children, women, the poor, and slaves. Reinvigorating these practices and traditions is an important aspect of long-term poverty alleviation in Africa and the African diaspora.

In the colonial period, as some of these traditions lost their power and as colonial rule and laws were introduced, Africans began to lose their sense of cultural identity and a new group of elites emerged to replace traditional rulers and to collaborate with the colonial powers. Although the colonial government reinvented aspects of indigenous culture that supported colonial rule, it also created new groups of elites from the natives. On a positive note, the tradition of market women's protest in colonial and postcolonial periods followed the traditional structure of ritual rebellion against what is perceived as oppression of poor people. 
Though the Ig6os brought the age of African independence, the magic of independence soon subsided as self-rule was haphazardly installed and the structures left by the departing colonialists undermined peaceful coexistence among different linguistic and ethnic groups that were forcefully situated under the jurisdiction of the same nation-state. In the first three decades of African independence, under systems of military rule, many African economies experienced significant growth as natural resources-particularly oil and minerals-were discovered. This was also a period when corruption was institutionalized and currencies were devalued to "inconvertible" foreign currency. Taking advantage of severely weakened developing states and the global economy, the World Bank and the International Monetary Fund (IMF) exploited conditions that turned these countries into the poorest in the world and developed nations into the wealthiest. The "structural adjustment policies" of the World Bank and IMF encouraged massive loans that, lacking alternatives, developing nations were forced to take for survival. Therefore, it is not surprising that throughout this period in Africa military coups were hatched, with new despotic rulers in khaki uniforms emerging. This situation continued into the late I9gos in most countries, when, with the support of the international community, many African states developed new democratic, though largely economically deprived, governments.

Given the complex historical experiences of the African peoples and African diasporic communities in the Caribbean and North America, the conversation on poverty calls for a radical rethinking of African philosophical, social, and ethical norms to understand how modernization, secular democratic ideals, and political transformation of the continent since independence, have impinged upon the norms, cultures, and indigenous African life today. For instance, as Elizabeth Amoah notes in her essay in this volume, one of the fundamental qualities of traditional African life is communal and common ownership of land and property. Following their colonial legacy, however, many African nations quickly adopted privatized systems at independence. Indeed, the breakdown of Africa's traditional common ownership of land and subsistence production is comparable to the massive closing of the commons in feudal England, when peasants were forcibly evicted from common lands and the commons were then used to develop agrarian capitalism, extend capitalist accumulation, and ensure a national wage-labor market. Privatization undermined the social welfare ethos predominant in rural African communities. The radical change from communal ownership to governmental control of communal properties provided the pretext for enacting many draconian laws and decrees by which very poor people in rural areas were deprived of their only earthly possessions: their lands. Lands were 
forcefully acquired for redistribution among the new rich and city entrepreneurs. Unfortunately, in places such as Nigeria and Kenya, this practice became a national program and many watched helplessly as millions of poor people were left destitute as the ethos of communal sharing gave way to complete deprivation. An exception was former Tanzanian president Julius K. Nyerere, one of Africa's most respected elder statesmen and peacemakers of the region, who established the ujamaa village program of communitybased farming collectives. Its failure due to mismanagement, however, led Western critics and cultural despisers to conclude, as did Peter Berger, that socialism has always been a failed ideology whenever it was practiced. Father James Schall's famous study Religion, Wealth, and Poverty claims that the actual cause of poverty in the world is ideological and insists that the "last great hope for the poor" is "democratic capitalism." Citing Tanzania, Schall wrote, "The best way to discover why Tanzania remains poor and depends on handouts is not to examine its soil or its rainfall, but to read the collected speeches of Mr. Julius Nyerere."

Judging from the poor assessment of Nyerere's program and Mugabe's current land redistribution program in impoverished Zimbabwe, one may conclude that African socialism and the adaptation of an indigenous African ethos to the fight against poverty are bound to fail. I am persuaded that this is not the case. The problem lies more in the implementation of the programs than in the ideological persuasion of these leaders. The partial success of Rwanda's ongoing National Poverty Reduction Program, based on ubudehe, "the traditional Rwandan practice and cultural value of working together to solve problems," clearly indicates how an indigenous-inspired poverty alleviation program can succeed. According to the architects of the program, "The objective of this Ubudehe Mukurwanya Ubuduken Program is to revive and foster collective action at community level. It is designed to work with and reinforce the on-going political and financial decentralizations process and to provide a direct injection of financial capital into the rural economy, aimed at overcoming one of the main obstacles to pro-poor economic growth."

\section{Responses to Poverty}

A number of policy initiatives have recently been set forward to address the issue of poverty in Africa. Faith-based initiatives have proven particularly popular and deserve attention. Since 1960, membership in Christian faiths in Africa has increased over 8o percent, from 6o million (in 1960) to 300 million (in 200I). ${ }^{10}$ Faith-based organizations in Africa are thus situated to take 
on significant roles in addressing underdevelopment and alleviating extreme crises. Many of Africa's most impoverished people are also deeply spiritual members of religious organizations. By joining religious social support networks, many achieve a sense of personal identity, unified community, and social solidarity and are able to call upon the combined resources of the faith organization to address the poverty and disease ravaging their communities. Using ancient religious teachings, religious denominations instill religious values as moral obligations to the faithful, who are obligated to alleviate poverty in ways that may be lacking in secular institutions, international development agencies, or local governments. Thus, on a global scale religious groups can serve as effective representatives for marginalized segments of third world peoples. Religious organizations can also compel national and local political leaders to discourage corruption in public, civic, and political life; to empower citizens to develop skills; to acknowledge rights; to elect responsible leaders; to address corruption of ethnic and political affiliations; and to dissuade Western governments from giving tax breaks to companies responsible for environmental disasters.

Indeed, in 2000 the Nairobi Conference entitled "Alleviating Poverty in Africa" was sponsored in partnership with the Council of Anglican Provinces of Africa and the World Bank, participating in a Council of Anglican Provinces of Africa (CAPA) training course for new bishops in Ibadan, Nigeria. The conference addressed the causes of poverty; political, economic, and social challenges; and ways to fight poverty by raising income and promoting empowerment, security, and opportunity in African nations. Seeing the spiritual as an essential component of development, these organizations committed to working with African communities to seek community-driven development, protect natural resources and environments, promote good governance by fighting corruption, and relieve debt. Further, some religious groups are directly embedded in the struggles against poverty by insisting through their lobbying groups that poverty be seen as a moral question of world economic policy. The Catholic social justice lobbying group, Network, for example, urges religious organizations to ask governments and corporations ethical questions regarding economic policy: How does policy affect the lives of people in poverty? How does policy improve the lives of people in poverty? How does policy affect their capacity to decide about their lives? ${ }^{11}$

Faith-based initiatives are not without problems, however. I argue that many Evangelical and Protestant groups should redefine their mission from one that focuses primarily on the saving of souls from eternal damnation to one that directly addresses the misery and poverty lived by many of their flock. They must address spiritual as well as material needs by cultivating a 
new mind-set similar to the notion of the "mission church" in the colonial era, in which the Bible and the plow were understood as mutually reinforcing. I understand faith-based initiatives as social programs developed by religious communities to eradicate and alleviate poverty, rejecting the popular understanding in the United States that faith-based initiatives, as defined by George W. Bush, are the state-sponsored redistribution of resources using the agency of religious communities. The latter understanding runs the risk of polarizing public opinion and engendering religious bigotry. Overall, however, religious bodies have long been involved in social welfare and charity without the support of the state. Beyond their peculiar meaning in America, faith-based initiatives imply the involvement of civil society at large, particularly in the postmilitary states of contemporary African nations.

The role civil society plays in poverty alleviation cannot be overemphasized. It has been widely argued that the chronic corruption in many failed African states has led to the growth of civil society. The excellent performance of the civil society in the postmilitary era, especially in the struggle for democratization, confirms that it needs to be strengthened today if nascent democracies in Africa are to survive. Progressive religious institutions constitute a significant segment of any nation's civil society, and developing programs to eradicate and alleviate poverty should be seen in that context. In the African situation, it is counterproductive to build a wedge between religious institutions and other civil society groups, such as trade unions, universities, and other nongovernmental organizations involved in the critical work of social change or social engineering. The Western notion of separating the spheres of influence of religion, state, and civil agencies may be foreign to Africans, hence the union of these spheres should not be assumed inappropriate in alleviating and eradicating poverty in Africa today through sustainable development.

An unexpected locus for poverty alleviation may be the international monetary bodies (the IMF and the World Bank) in partnership with religious organizations, particularly churches. Regarded as credible partners, many churches in Africa are forging new partnerships with the World Bank, and these partnerships may prove beneficial as the bank not only provides expertise in specific aspects of poverty and public policy but also has special access to national and international decision makers. The bank brings a global perspective and financial resources to alleviating poverty, as the largest source of multilateral development assistance to Africa. ${ }^{12}$

Though partnering with the World Bank may make new opportunities available, it is essential that the church always maintain its prophetic voice 
in such relationships or partnerships. Instead of denouncing partnership with the World Bank or the IMF as some churches have done, the church should insist on its prophetic tradition, which provides meaningful critique of global injustice while simultaneously sponsoring and collaborating with credible organizations. The story of the prophet Nathan related in the Old Testament book 2 Samuel illustrates the possibility of the prophet speaking truth to power. In 2 Samuel, the prophet Nathan was sent to reprimand King David for slaying Bathsheba's husband in order to take Bathsheba for himself to be his wife (2 Samuel I2:I-9). Nathan tells David the parable of a very rich man who had many flocks and a poor man who had only one precious little lamb and who raised the lamb lovingly as part of his family. Now the rich man, ignoring his many herds, took the poor man's lamb and had it prepared for dinner guests. On hearing the story, David became enraged at the perpetrator of this wicked deed, declaring that the rich man deserved to die because he showed no compassion. Nathan thus delivered the accusation to King David, "Thou art the man!" This old biblical story is useful in today's situation of unequal power among nations, corporations, and peoples. A skilled communicator, Nathan raised David's consciousness such that David was able, by acknowledging evil in one case, to recognize evil in himself.

The impact of poverty on gender relations in Africa, especially the status of women and the responses of women's religious, cultural, and social institutions to conditions of poverty is also profoundly important and is highlighted in Barbara Bailey's contribution to this volume. All available data suggest that poverty in Africa disproportionately affects women and children. The Council of Anglican Provinces of Africa in partnership with the World Bank issued a statement on gender and poverty in sub-Saharan Africa, declaring that if Africa is to achieve equitable growth and sustainable development, then women must have access to and control of productive, human, and social capital assets. ${ }^{13}$

The church sees the inherent partnership between men and women as originating in Creation and its breakdown as sinful. But the church's missionary heritage created structured, unequal gender roles. Thus, the church must now provide space for women to express and contribute their resources and gifts in a more participatory and equal manner, thus enabling the full range of Africa's human resources to alleviate poverty. The church must increase awareness of injustices against women through empowerment programs and gender training for all worshippers. The majority of church members in Africa are women, making gender equality a moral imperative as well as a developmental objective that is central to the church's 
survival. The church must remove the rigid structures of its community life in order to improve the status of women. Further, women must secure access to and control of a diverse range of productive, human, and social capital.

Religious groups can offer equitable provisions for women to articulate their resources and gifts, to address the female and child culture of poverty in Africa, to raise consciousness-supporting empowerment programs, and to offer gender-awareness training. Religious groups can change rigid structures of religious community life to promote women's leadership and to assess the impact of religious programs targeted to rural women, encouraging all segments of society to work together to alleviate poverty. Indeed, the Anglican Church's Mothers Union, the Women's Guild, and numerous other women's groups in many Christian denominations are doing precisely that. Peace depends on economic justice, social harmony, and spiritual sanctity of life. Religious groups identify the root cause of conflict in people's refusal to see any "good" in "the other" and its solution in the willingness to accuse and implicate one's self and one's own group as part of the problem. Forgiveness and reconciliation, based on this analysis, is the religious group's comparative advantage. In a conflict situation, religious groups can-and should-offer a permanent institutional framework that provides continuity and social stability. ${ }^{14}$

\section{Conclusion}

In 2005, when the developed world pledged to halve poverty in the world by 2015 and ultimately "make poverty history," there was a happy response from the African people that finally the developing world was awakening to its responsibility to aid the world's most impoverished peoples. All indications, however, suggest that not only has the developed world reneged on its promises, but it is not at all committed to "making poverty history." The Millennium Development Goals, as noble as they are, set a Herculean task for poverty alleviation because of the fundamental structures of the political, economic, and social orders that are entrenched in the world today, which render any meaningful reform improbable. All available statistics suggest that those who are most affected by the world poverty crisis are in the regions of Africa and the Caribbean, from where most of the case studies in the present volume originate. It is perhaps in the context of this crisis that the Pan-African approach and response to poverty was planned and carried out by some of the best scholarly minds living in the impoverished regions in question. Religion and Poverty: Pan-African Perspectives is a small but impor- 
tant contribution to the pressing challenge that poverty in Africa and the African diaspora present to the world.

\section{Notes}

I. Biblical quotations throughout this book are from the Revised Standard Version.

2. Paul Bouvier, "The Mission of the Churches amid the Social Reality of Rich and Poor Nations," in God and Global Justice: Religion and Poverty in an Unequal World, ed. Frederick Ferre and Rita H. Mataragnon (New York: Paragon House, I985), II3.

3. Ibid.

4. John Iliffe, The African Poor: A History (Cambridge: Cambridge University Press, 1987), 2.

5. Bengt Sundkler and Christopher Steed, A History of the Church in Africa (Cambridge: Cambridge University Press, 2000), 9I4.

6. Elizabeth Allo Isichei, Voices of the Poor in Africa (Rochester, N.Y.: University of Rochester Press, 2002), 93 and I69. See also Steven Feierman, Peasant Intellectuals: Anthropology and History in Tanzania (Madison: University of Wisconsin Press, I99o).

7. J. D. Y. Peel, Religious Encounter and the Making of the Yoruba (Indianapolis: Indiana University Press, 2000).

8. James V. Schall, Religion, Wealth, and Poverty (Vancouver: Fraser Institute, I990), I5.

9. Africa Forum, "Ubudehe to Fight Poverty," Africa Notes, November/December 2002, I.

ro. Deryke Belshaw, Robert Calderisi, and Chris Sugden, eds., Faith in Development: Partnership between the World Bank and the Churches of Africa (Washington, D.C.: World Bank, 200I), 3.

II. Neil Chethik, "Global Issues: Trends on Collision Course with Justice," UU World I4.6 (November/December 2000): I8-22.

I2. Belshaw, Calderisi, and Sugden, Faith in Development, 8.

I3. Ibid., Io.

I4. Ibid., I4. 